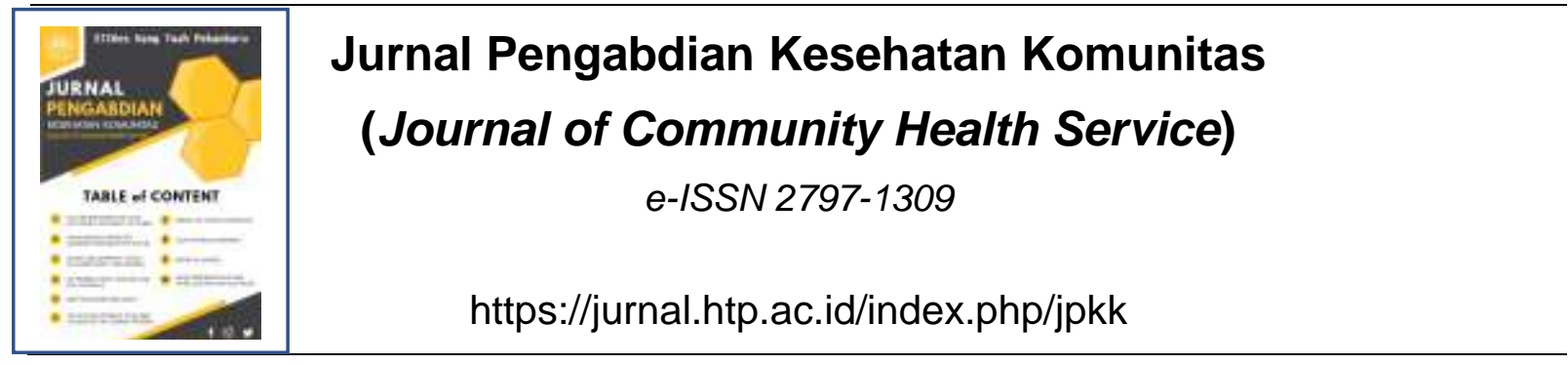

\title{
Strategi Pendidikan Kesehatan pada Ibu Hamil di Masa Pandemi
}

\author{
Hasnah, Nurhidayah, Nurul Fadhilla Gani, Risnah, Arbianingsih, Huriati, Eka \\ Hadrayani, Maria Ulfah Azhar, Muthaharah \\ Prodi Keperawatan, FKIK UIN Alauddin Makassar \\ Email: nurhidayah.ners@uin-alauddin.ac.id
}

\begin{tabular}{l}
\hline Histori artikel \\
\hline Received: \\
$23-08-2021$
\end{tabular}

23-08-2021

Accepted:

29-08-2021

Published:

02-09-2021

\begin{abstract}
Abstrak
Kesehatan ibu hamil akan menentukan kesehatan bayi yang akan dilahirkan. Hal tersebut juga merupakan perhatian besar bagi pemerintah. Ibu hamil, membawa calon generasi penerus bangsa yang secara produktif akan berkontribusi besar terhadap kemajuan bangsa dan negara. Pentingnya kesehatan Ibu, dapat dilihat dari kebijakan pemerintah yang menjadikan penurunan Angka Kematian Ibu (AKI) sebagai salah satu target SDG's 2030 dan indikator keberhasilan pembangunan nasional. Ibu hamil adalah kelompok rentan terlebih disituasi dan kondisi pandemic. Berbagai upaya dilakukan untuk tetap menjaga kesehatan ibu dan bayinya selama proses kehamilan sampai persalinan. Kabupaten Gowa merupakan kabupaten dengan jumlah kasus covid tertinggi kedua di Sulawesi Selatan, maka ini menjadi dasar pelaksanaan pengabdian masayarakat di wilayah kerja Puskesmas Bajeng Kabupaten Gowa. Metode yang digunakan adalah memberikan penyuluhan kesehatan dalam bentuk gallery walk dengan tujuan meningkatkan pengetahuan ibu hamil agar mampu tetap menjaga kesehatannya. Berbagai tema penting pada penyuluhan ini antara lain: anemia pada ibu hamil, resiko 4T pada ibu hamil, mengenal tanda-tanda bahaya kehamilan, manajemen stress pada ibu hamil, dan nutrisi yang dibutuhkan ibu hamil serta tetap melakukan pemeriksaan kehamilan selama pandemic. Selama kegiatan berlangsung para ibu hamil antusias memperhatikan setiap materi yang diberikan dan aktif berdiskusi. Diakhir penyuluhan kami evaluasi secara langsung terkait pengetahuan ibu hamil tentang materi-materi yang sudah diberikan. Mereka sangat senang dengan adanya kegitan ini, dan berharap akan ada kegiatan lanjutan. Maka dari itu kami menyarankan kepada pihak-pihak terkait yaitu kepala puskesmas dan para tenaga kesehatan untuk tetap melaksanakan penyuluhan kesehatan rutin dan kembali mengaktifkan posyandu ibu hamil di masa pandemic covid 19 dengan tetap menerapkan protocol kesehatan.
\end{abstract}

Kata Kunci: Kesehatan Ibu Hamil, Masa Pandemi, Galery Walk 


\begin{abstract}
The health of pregnant women will determine for health status of the baby. This is also a main concern for the government. Pregnant women bring prospective future generations to the nation who will productively contribute greatly to the progress of the nation. The importance of maternal health can be seen from the government's policy that the reduction of the Maternal Mortality Rate (MMR) is one of the SDG's 2030 targets and an indicator of the success of national development. Pregnant women are a vulnerable group, especially in pandemic situations and conditions. Various efforts were made to maintain the health of mothers and babies during pregnancy until delivery. Gowa Regency is a district with the second highest number of Covid case in South Sulawesi. Therefore, it became the basis for implementation of community service in the working area of the Bajeng Public Health Center, Gowa Regency. The method used is to provide health education in the form of a gallery walk with the aim of increasing the knowledge of pregnant women in order to maintain their health. Various important themes in this counseling include: anemia in pregnant women, the risk of $4 \mathrm{~T}$ in pregnant women, recognizing the symptoms and danger signs in pregnancy, stress management for pregnant women, and nutrition needed by pregnant women and continuing to carry out pregnancy check-up during the pandemic period. During the activities, pregnant women were enthusiastically paying attention to each material provided and actively discussing. At the end of the counseling, we immediately evaluated the knowledge of pregnant women regarding in the materials that had been given. They were very happy with these activities, and looking forward to such activities next time. Therefore, we suggest to related parties, namely the head of the public health center and health workers, to continue to carry out health education regularly and to reactivate the integrated healthcare center for pregnant women during the COVID-19 pandemic period while still implementing health protocols.
\end{abstract}

Keyword: Health Education, Maternal Health, Pregnancy, Pandemic Periode

\title{
PENDAHULUAN
}

Kehamilan merupakan salah satu periode penting dalam kehidupan seorang wanita. Dalam periode ini, ibu hamil akan mengalami berbagai perubahan yang kompleks, baik itu fisik maupun psikososial (Avelyn, 2012). Perubahan tersebut pada dasarnya bersifat fisiologis dan normal, namun berbagai ketidakseimbangan fisik dan hormonal mengakibatkan dirasakannya berbagai gangguan. Gangguan tersebut dapat berupa keluhan fisik seperti mual dan muntah, gangguan kebutuhan nutrisi, istirahat tidur, maupun masalah psikososial, seperti depresi (Bobak, 2012).

Kesehatan ibu hamil merupakan perhatian besar bagi pemerintah. Ibu hamil, 
membawa calon generasi penerus bangsa yang secara produktif akan berkontribusi besar terhadap kemajuan bangsa dan negara. Pentingnya kesehatan lbu, dapat dilihat dari kebijakan pemerintah yang menjadikan penurunan Angka Kematian Ibu (AKI) sebagai salah satu target SDG's 2030 dan indikator keberhasilan pembangunan nasional (Bappenas, 2012; Kementerian kesehatan RI, 2014; Bappenas, 2015). Ibu hamil juga merupakan kelompok yang rentan terlebih disituasi dan kondisi pandemic. Saat ini tentu berbagai upaya harus kita lakukan untuk tetap menjaga kesehatan ibu hamil selama menjalani proses kehamilannya sampai proses persalinan begitu juga terhadap bayi yang dikandungnya.

Menurut Sumber Data dan Informasi Kesehatan Indonesia (SDKI) tahun 2014, Angka Kematian Ibu di Indonesia akibat kehamilan, persalinan, dan nifas mengalami peningkatan sejak 2012, yaitu dari 228 menjadi 359 kematian ibu per 100.000 kelahiran hidup (Bappenas, 2015; Kementerian Kesehatan RI, 2015). Peningkatan ini merupakan masalah, karena tidak mencapai target MDG's 2015, dimana diharapkan penurunan AKI mencapai 102 per 100.000 kelahiran hidup (Kementerian kesehatan, 2015). Angka ini masih relatif tinggi dibandingkan dengan negara-negara ASEAN lainnya. Pada tahun 2007 misalnya saat AKI di Indonesia mencapai 228, AKI di Singapura hanya 6 per 100.000 kelahiran hidup, Brunei dengan jumlah 33 per 100.000 kelahiran hidup, Filipina 112 per 100.000 kelahiran sementara Malaysia dan Vietnam sama-sama mencapai 160 per 100.000 kelahiran hidup (Kementerian Kesehatan RI, 2015).

Kenaikan ini menimbulkan pertanyaan besar, karena dalam 5 tahun terakhir telah banyak program yang direncanakan dan dilaksanakan oleh pemerintah untuk menurunkan $\mathrm{AKI}$, namun penurunan AKI tetap belum mencapai target. Program tersebut mencakup financial program yakni jampersal, bantuan operasional kesehatan (BOK), dan jaminan kesehatan nasional (JKN). Program lainnya yaitu, Expanding maternal and neonatal survival (EMAS) (Kementerian Kesehatan RI, 2015)

Tiga penyebab terbesar kematian Ibu adalah hipertensi dalam kehamilan (HDK), perdarahan post-partum dan infeksi (Kementerian Kesehatan, 2015). Dan self-care yang kurang menjadi salah satu prediktornya. Self-care yang kurang selama kehamilan menjadi salah satu penyebab langsung dan tidak langsung terjadinya komplikasi kehamilan maupun persalinan (Kohan, Ghasemi, \& Dodangeh, 2007; Gamelia, Sistiarani, dan Masfiah, 2013). Ditemukan data yang dapat mengindikasikan masih kurangnya self-care management Ibu hamil di Kota Makassar, yang menjadi prediktor kuat penyebab buruknya health outcomes pada Ibu maupun Bayi. Dari Binkesmas Dinas Kesehatan Kota Makassar (2014) diperoleh, meningkatnya jumlah kelahiran BBLR dari 1,96 di tahun 2012 menjadi 2,48 di tahun 2013 dan menurunnya cakupan imunisasi TT2 dari 91,2\% menjadi 86,1\% di tahun 2013 (Dinas 
Kesehatan Kota Makassar, 2014). Selain hal tersebut, saat ini semakin diperburuk dengan adanya virus covid 19 .

Prevalensi kasus di Sulawesi selatan sebanyak 94.848 dan ditetapkan sebagai salah satu wilayah zona merah covid, dimana Kabupaten Gowa merupakan kabupaten tertinggi kedua setelah Makassar dengan jumlah kasus 8746 kasus. Tentu hal ini harus menjadi perhatian lebih khususnya bagaimana petugas kesehatan menjaga kesehatan ibu dan bayi dimasa pandemic. (Dinas Kesehatan Kota Makassar, 2021). Penelitian yang dipublikasikan oleh Lancet Global Health menunjukkan, wanita hamil menghadapi risiko penyakit parah dan kematian yang lebih tinggi bila terinveksi virus corona. Tidak hanya itu, analisis dari 40 penelitian di 17 negara juga menemukan kerugian lain pada ibu hamil dimasa pandemic. Hal ini termasuk lahir mati (stillbirth) yang meningkat menjadi 28\% (Luo, Y \& Yin K, 2020)

Dari penjelasan diatas jelas bahwa terdapat beberapa faktor yang dapat mempengaruhi kesehatan dan bahkan kematian ibu selama menjalani proses kehamilan terlebih di pasca pandemic seperti saat ini. Sehingga penting untuk dilakukan berbagai upaya salah satunya memberikan edukasi kepada ibu hamil bagaiman cara tetap menjaga kondisi kesehatan ibu dan juga bayi mulai dari kehamilan hingga persalinan di masa pandemi.

\section{TUJUAN}

Tujuan kegiatan pengabdian masyarakat ini adalah agar ibu hamil di Wilayah kerja Puskesmas Bajeng dalam hal mengetahui upaya-upaya untuk tetap mempertahankan kesehatannya dan bayi yang dikandungnya dimasa pandemi Covid 19.

\section{METODE}

Kegiatan pengabdian dilakukan melalui edukasi dengan model gallery walk untuk meningkatkan dan mempertahankan kesehatan ibu hamil selama pandemi dengan berbagai tema antara lain: cara mencegah anemia pada ibu hamil, resiko 4T pada ibu hamil, mengenal tanda-tanda bahaya kehamilan, manajemen stress pada ibu hamil, dan nutrisi yang dibutuhkan ibu hamil yang merupakan salah satu faktor penting untuk tetap menjaga imun tubuh serta bagaimana ibu hamil harus menjaga protokol kesehatan ketika berada diluar rumah, menghindari kerumunan, agar terhindar dari virus covid 19 yang bisa membahayakan ibu maupun bayi yang. Kegiatan edukasi menggunakan metode ceramah dan diskusi. Alat bantu yang digunakan dalam penyuluhan yaitu poster dan leaflet yang diberikan kepada tiap ibu hamil yang hadir. Pelaksanaan pengabdian dilakukan diwilayah kerja Puskesmas Bajeng Kabupaten Gowa. Ibu hamil yang hadir dalam kegiatan pengabdian ini sejumlah 30 orang. Kegiatan pengabdian ini dimulai dengan tahap persiapan, lalu dilanjutkan dengan tahapan pelaksanaan dan monitoring evaluasi. Tahap persiapan berupa persiapan media yaitu menyiapkan leaflet dan poster, pertemuan dan 
diskusi dengan instansi tempat pelaksanaan kegiatan pengabdian masyarakat yaitu pertemuan dengankepala puskesmas dan penanggung jawab program PTM di Puskesmas Bajeng,menentukan tempat dan jadwal pelaksanaan kegiatan hingga melakukan persiapan pelaksanaan kegiatan penyuluhan kesehatan. Tahapan pelaksanaan yaitu memberikan edukasi kepada ibu hamil melalui metode gallery walk, sementara tahap monitoring evaluasi dilakukan dalam evaluasi langsung terhadap materi yang telah disampaikan.

\section{HASIL}

Kegiatan Pengabdian Kepada Masyarakat tentang "Menjaga Kesehatan Ibu Hamil di Masa Pandemi" di Puskesmas Bajeng Kabupaten Gowa diikuti oleh 30 ibu hamil. Kegiatan dilaksanakan pada tanggal 14 Juni Tahun 2021 yang dimulai pukul 09.00 WIB sampai dengan 12.00 WIB. Pelaksana kegiatan melakukan kordinasi dengan Kepala Puskesmas dan penanggung jawab program PTM di Puskesmas Bajeng untuk perizinan kegiatan pengabdiantersebut.
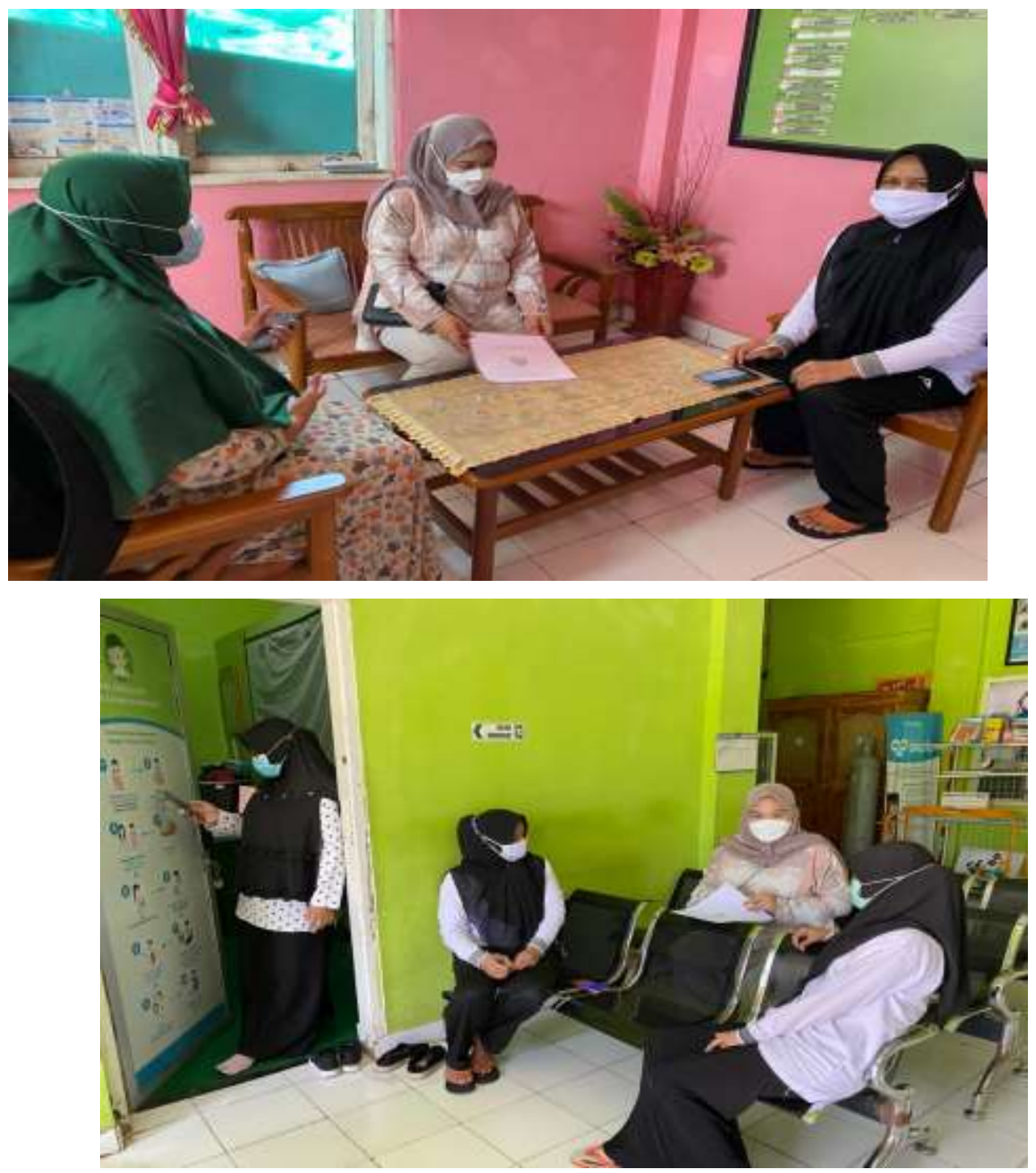


\section{Gambar 1 dan 2 Pertemuan antara tim keperawatan maternitas UIN Alauddin dengan Kepala Puskesmas dan penanggung jawab program PTM di Puskesmas Bajeng}

Bentuk kegiatan pengabdian masyarakat yang kami lakukan adalah Pendidikan Kesehatan untuk meningkatkan pengetahuan melalui edukasi dengan model gallery walk. Strategi tersebut digunakan untuk menjaga jarak dan kontak langsung antara ibu hamil selama pandemic. Sebelum diberikan penyuluhan ibu hamil dilakukan pengukuran tekanan daran dan pengkajian awal tentang kondisi dan keluhan yang dirasakan kemudian lanjut ke pemberian materi penyuluhan dimana kami membagi beberapa titik untuk menempelkan poster penyuluhan sehingga ibu hamil bisa secara bergantian untuk mendapatkan materi materi yang telah kami siapkan dengan tentunya menerapkan protokol kesehatan. Dimana terdapat 5 gallery yang dikunjugi ibu hamil dengan tema yang berbeda sehingga harapannya ibu hamil dan keluarga yang mendampingi mampu mengetahui berbagai hal dan upaya untuk tetap mempertahankan kesehatan ibu hamil di masa pandemik.

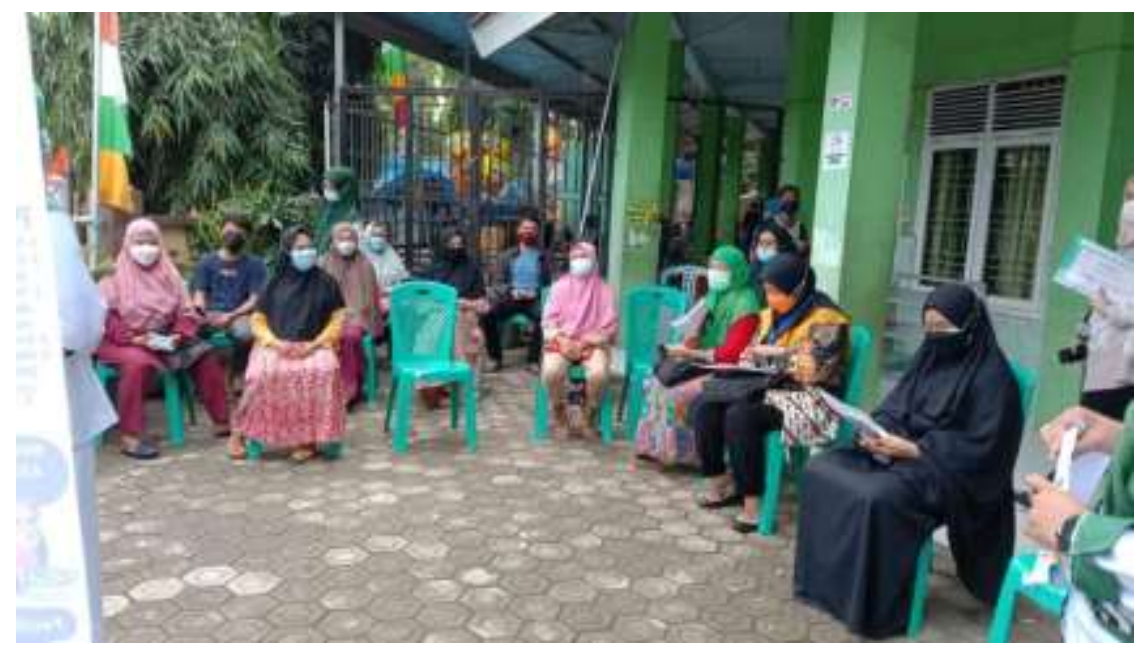

Saat pelaksanaan berlangsung ibu hamil dibekali leaflet untuk dibaca dan dipahami lebih mudah terkait materi materi yang dibawakan dan diakhir sesi kami memberikan kesempatan untuk ibu hamil menanyakan. 


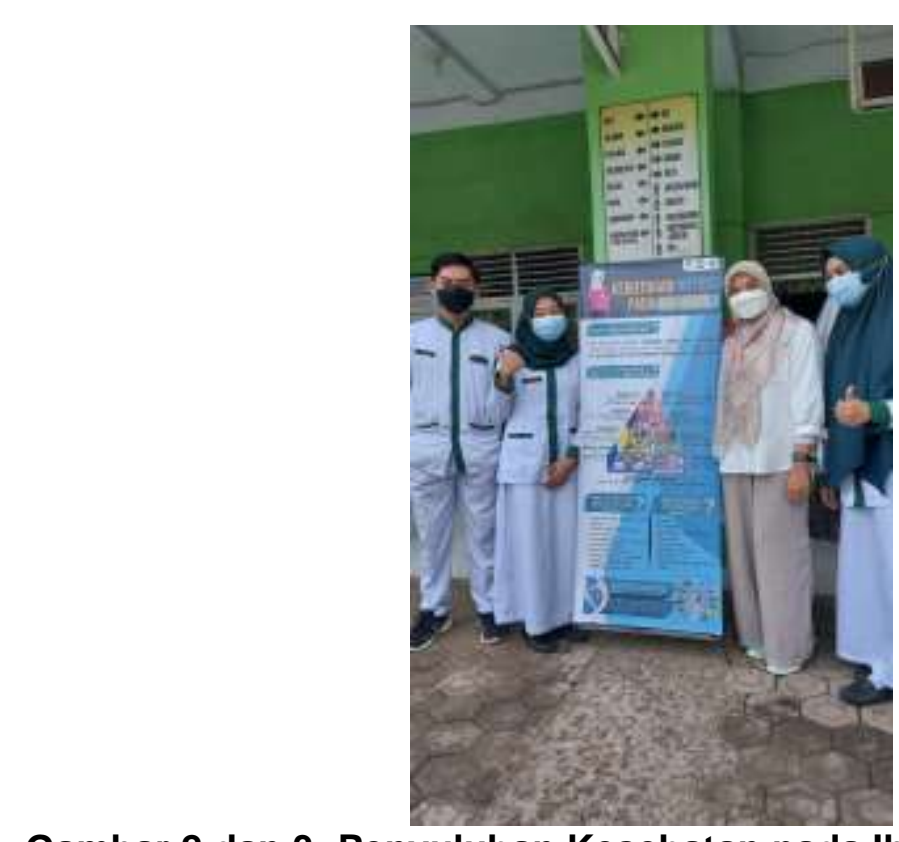

Gambar 2 dan 3: Penyuluhan Kesehatan pada Ibu Hamil di Halaman

Puskesmas Bajeng.

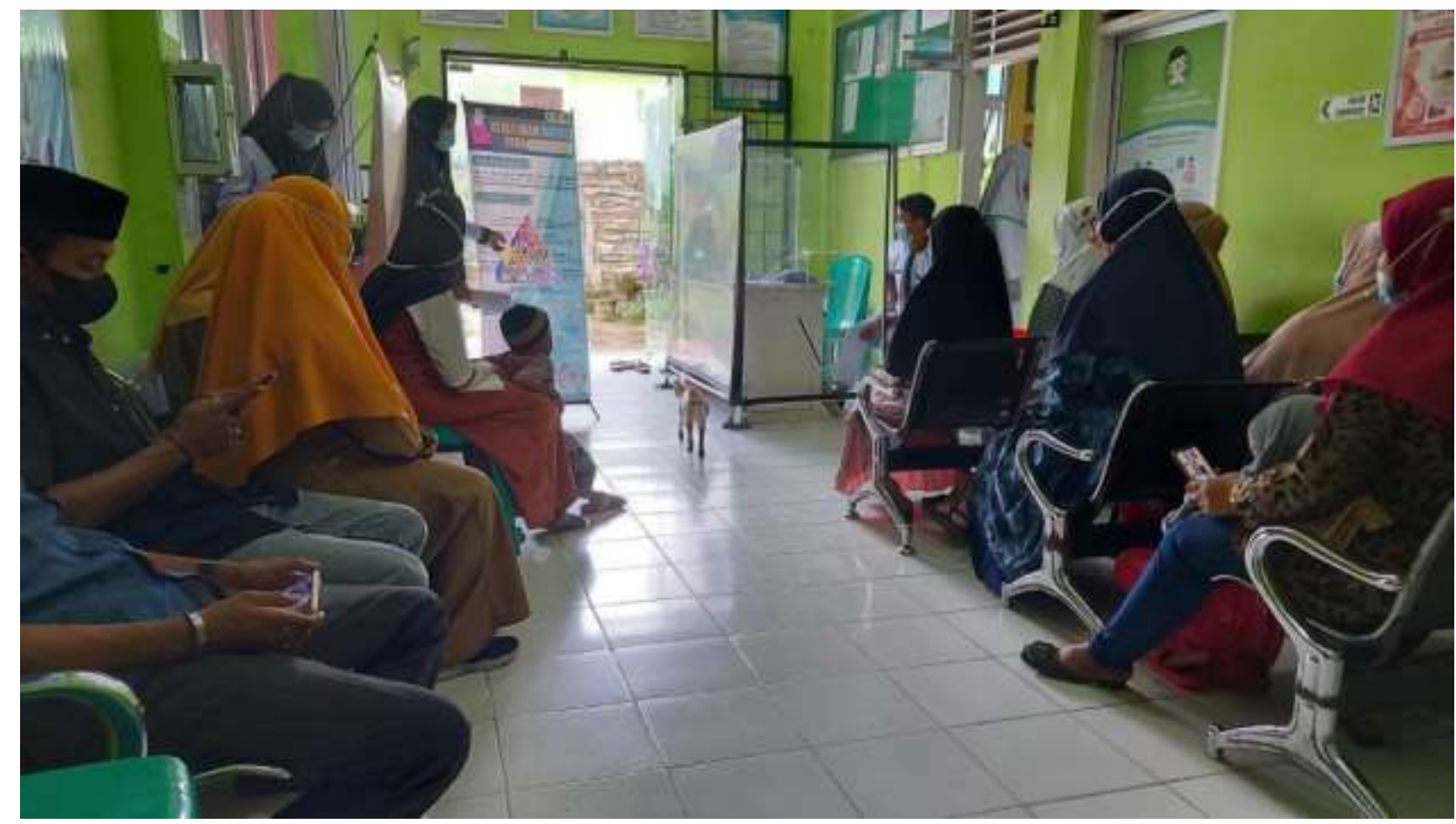

Gambar 4 : Penyuluhan Kesehatan 


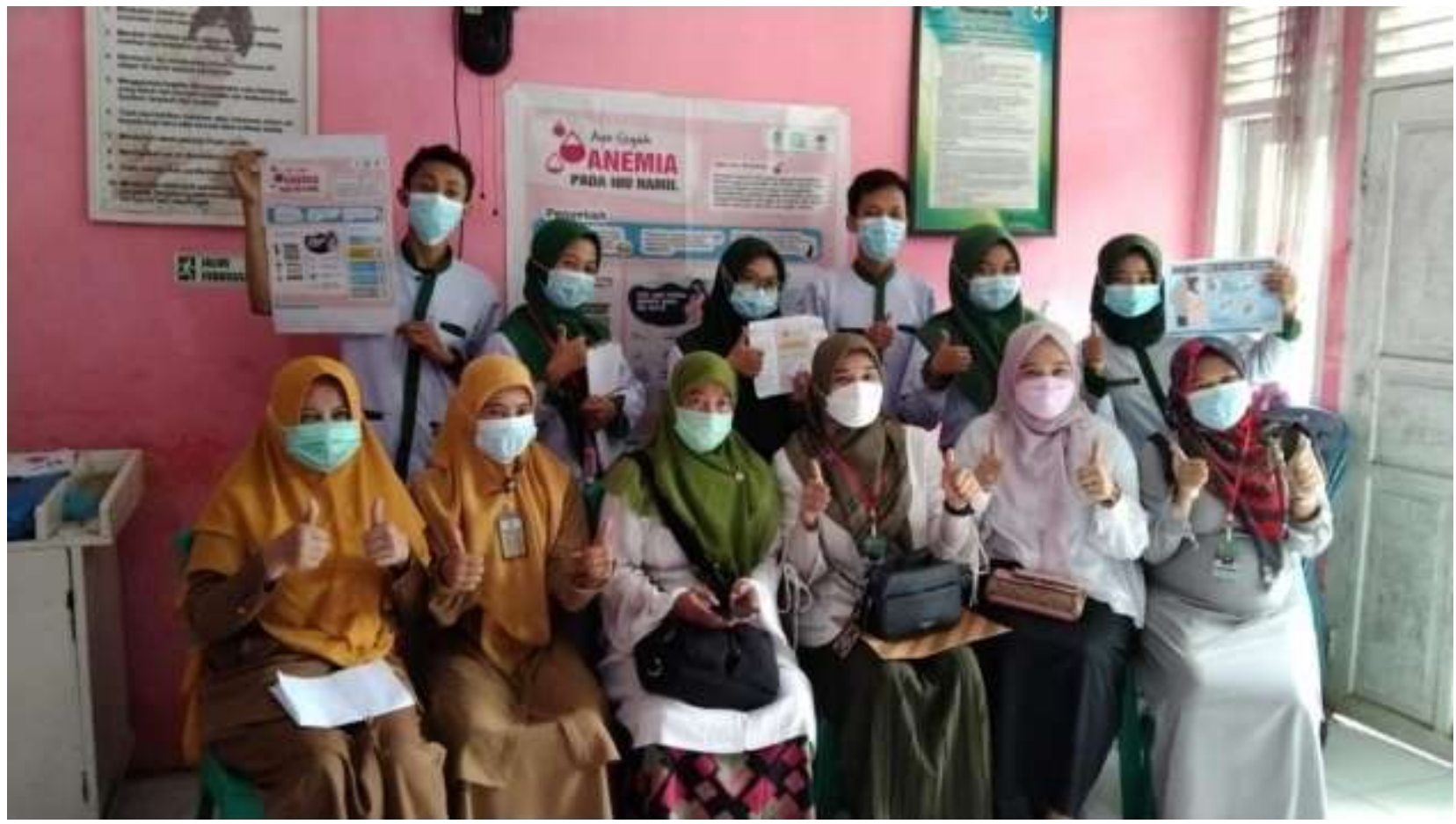

Pada Ibu Hamil di Ruang ANC

Gambar 5. Foto Bersama peserta penyuluhan dan Petugas Puskesmas Bajeng

Ibu hamil merasa antusias dan senang dengan kegiatan pengabdian ini, karena kegiatan ini dapat meningkatkan pengetahuan mereka tentang upaya menjaga kesehatan ibu hamil di masa pandemi. Mereka berharap kegiatan ini dapat dilakukan secara berkelanjutan. pihak puskesmas juga menilai positif dengan kegiatan pengabdian yang telah dilakukan karena juga membantu program puskesmas untuk menekan AKI (Angka Kematian Ibu) dan Kejadian Covid pada Ibu hamil.

\section{PEMBAHASAN}

Kegiatan pengabdian masyarakat tentang bagaimana upaya untuk tetap mempertahankan kesehatan ibu hamil di masa pandemic sangatlah efektif dan tepat dilaksanakan karena ibu hamil merupakan kelompok yang rentan/berisiko tinggi terlebih saat pandemic dimana diketahui bahwa wilayah Gowa merupakan kabupaten ke 2 tertinggi setelah Makassar dengan angka kasus covid 67 kasus (Antara, n.d.) dan juga dilansir oleh satgas covid 19 menyatakan bahwa Makassar merupakan prevalensi tertinggi di Sulawesi selatan di ikuti oleh Kabupaten Gowa (Prevalensi covid Makassar, 2021). Penelitian yang dipubliaksi oleh (Wei et al., 2021) menyatakan bahwa dampak penyakit coronavirus 2019 
(COVID-19) pada kesehatan ibu dan bayi baru lahir tidak jelas. Kami bertujuan untuk mengevaluasi hubungan antara infeksi parah sindrom pernafasan akut coronavirus 2 (SARS-CoV-2) selama kehamilan dan hasil kehamilan yang berbahaya.

Pendidikan Kesehatan di harapkan dapat meningkatkan pengetahuan ibu hamil. Pendidikan Kesehatan sangat diperlukan oleh ibu hamil hal tersebut dikemukakan oleh (Villar et al., 2021) menyatakan bahwa COVID-19 dalam kehamilan dikaitkan dengan peningkatan yang konsisten dan substansial dalam morbiditas dan mortalitas ibu yang parah dan komplikasi neonatal ketika wanita hamil dengan dan tanpa diagnosis COVID-19 dibandingkan. Temuan ini harus mengingatkan individu hamil dan dokter untuk menerapkan secara ketat semua tindakan pencegahan COVID-19 yang direkomendasikan. Pendidikan Kesehatan yang digunakan adalah strategi pembelajaran dengan menggunakan gallery work sehingga ibu hamil akan tetap menjaga jarak dengan yang lainnya. Selain itu ibu hamil akan leluasa bertanya tentang Kesehatan selama masa kehamilan. Kondisi di Puskesmas Bajeng juga diperoleh masih rendahnya pengetahuan ibu hamil terhadap informasi penting selama kehamilan dan persiapan menuju persalianan. Kegiatan ini tentu akan sangat bermanfaat bagi ibu hamil dan keluarga. Masa kondisi pandemik Covid-19 dimana terdapat kekhawatiran bagi ibu hamil untuk datang memeriksakan kondisi kehamilannya ke Puskesmas karena takut tertular covid-19.

Pemberian edukasi menjadi sangat penting untuk membuat ibu hamil melek terhadap informasi kesehatan, bagaimana mengakses, memahami dan menggunakan informasi dan pelayanan kesehatan untuk membuat keputusan tentang perawatan kesehatan dalam upaya meningkatkan dan mempertahankan kesehatannya serta membantu individu/masyarakat dalam pengambilan keputusan yang tepat tentang kesehatan mereka. Penyuluhan kesehatan merupakan kegiatan yang memberikan informasi kesehatan kepada masyarakat yang dapat mempengaruhi perubahan perilaku, salah satunya perubahan pengetahuan. Dengan diberikannya edukasi, ibu hamil mendapat pembelajaran yang menghasilkan suatu perubahan dari yang sebelumnya belum mengetahui menjadi mengetahui dan yang dahulu belum memahami menjadi memahami.

\section{SIMPULAN}

Terdapat peningkatan pengetahuan ibu hamil setelah dilakukan Pendidikan kesehatan tentang upaya-upaya untuk menjaga kesehatan ibu hamil di masa pandemi. Ibu hamil berkomitmen untuk menerapkan gaya hidup sehat menghindari keluar rumah dan berkerumun jika tidak perlu, tetap rutin memeriksakan kandungan sesuai dengan jadwal yang ditentukan dengan menerapkan protokol kesehatan serta tetap menjaga nutrisi yang seimbang dan memperhatikan asupan makanan untuk mencegah anemia dan 
masalah kesehatan lainnya baik ibu maupun bayi yang dikandungnya. Disarankan kepada Kepada pihak-pihak yang terkait seperti puskesmas bekerjasama untuk dapat memaksimalkan kegiatan penyuluhan kepada ibu hamil sebagai kelompok beresiko dimasa pandemic mengingat tingginya kasus covid di Kabupaten Gowa .

\section{UCAPAN TERIMAKASIH}

Ucapan terimakasih kami sampaikan kepada Pihak Puskesmas Bajeng Kabupaten Gowa beserta jajarannya karena telah membantu kami dalam pelaksanaan kegiatan pengabdian masyarakat dan juga lami mengucapkan terimakasih kepada para lbu hamil beserta keluarga yang datang mendampingi untuk meluangkan waktunya mendengarkan dan menyimak dengan baik setiap materi yang kami bawakan.

\section{DAFTAR PUSTAKA}

Prevalensi covid Makassar, (2021).

Villar, J., Ariff, S., Gunier, R. B., Thiruvengadam, R., Rauch, S., Kholin, A., Roggero, P., Prefumo, F., do Vale, M. S., Cardona-Perez, J. A., Maiz, N., Cetin, I., Savasi, V., Deruelle, P., Easter, S. R., Sichitiu, J., Soto Conti, C. P., Ernawati, E., Mhatre, M., ... Papageorghiou, A. T. (2021). Maternal and Neonatal Morbidity and Mortality Among Pregnant Women With and Without COVID-19 Infection: The INTERCOVID Multinational Cohort Study. JAMA Pediatrics, 175(8), 817-826.

https://doi.org/10.1001/jamapediatrics.2021.1050

Wei, S. Q., Bilodeau-Bertrand, M., Liu, S., \& Auger, N. (2021). The impact of COVID-19 on pregnancy outcomes: A systematic review and meta-analysis. Cmaj, 193(16), E540E548. https://doi.org/10.1503/cmaj.202604 